\title{
Multiple Acyl-Coenzyme A Dehydrogenation Disorder Responsive to Riboflavin: Substrate Oxidation, Flavin Metabolism, and Flavoenzyme Activities in Fibroblasts ${ }^{1}$
}

\author{
WILLIAM RHEAD, VICKIE ROETTGER, TERESA MARSHALL. AND BRAD AMENDT
}

Department of Pediatrics. Lniversity of Iowa. Iowa City: Iowa 52242

\begin{abstract}
Multiple acyl-CoA dehydrogenation disorders result from generalized defects in intramitochondrial acyl-CoA dehydrogenation. Fibroblasts from a riboflavinresponsive multiple acyl-CoA dehydrogenation disorder patient catabolized ${ }^{14} \mathrm{C}$-butyrate, -octanoate, and -leucine normally after culture in riboflavin-supplemented medium $(2 \mathrm{mg} / \mathrm{L})$. After culture in riboflavin-depleted medium $(\leq 1.4 \mu \mathrm{g} / \mathrm{L})$, his cells oxidized the same substrates poorly at 20 to $33 \%$ of control $(p<0.05)$. Patient cells incubated in a wide range of $\mathrm{D}-\left[2-{ }^{14} \mathrm{C} \mid\right.$ riboflavin concentrations $(3$, 31.4, and $100 \mu \mathrm{g} / \mathrm{L}$ ) synthesized ${ }^{14} \mathrm{C}$-flavin mononucleotide and ${ }^{14} \mathrm{C}$-flavin adenine dinucleotide (FAD) normally and had normal cytosolic ${ }^{14} \mathrm{C}$-flavin mononucleotide and ${ }^{14} \mathrm{C}$ FAD contents, which argues against defects in cellular riboflavin uptake and conversion to flavin mononucleotide and FAD. After culture in $31.4 \mu \mathrm{g}{ }^{14} \mathrm{C}$-riboflavin/L for 2 wk, ${ }^{14} \mathrm{C}$-FAD specific radioactivities plateaued and were similar in patient and control cells. However, culturing these uniformly labeled cells in riboflavin-depleted medium for $2 \mathrm{uk}$ lowered the patient's cellular ${ }^{14} \mathrm{C}-\mathrm{FAD}$ content to only $23 \%$ of control levels. Similarly, after incubation in low ${ }^{14} \mathrm{C}$-riboflavin concentrations $(4.4 \mu \mathrm{g} / \mathrm{L})$, the patient's mitochondrial ${ }^{14} \mathrm{C}$-FAD content was only $51 \%$ of control after $1 \mathrm{~h}$ and $29 \%$ of control at $4 \mathrm{~h}$. After a $4-\mathrm{h}$ incubation in a high physiologic concentration of ${ }^{14} \mathrm{C}$-riboflavin $\mathbf{3 1 . 4}$ $\mu \mathrm{g} / \mathrm{L})$, which raised the patient's cellular ${ }^{14} \mathrm{C}$-FAD levels 3- to 4-fold, his mitochondrial ${ }^{14} \mathrm{C}$-FAD content rose to normal; control values did not change. We also investigated possible defective FAD binding to flavoenzymes essential for acyl-CoA dehydrogenation. Medium-chain acyl-CoA dehydrogenase activities did not fall significantly in either patient or control mitochondria from cells cultured in riboflavin-depleted medium. However, after culture in riboflavin-depleted medium, the patient's electron transfer flavoprotein activity fell to $59 \%$ of control in mitochondrial preparations, which is compatible with decreased matrix FAD content. We postulate that defective maintenance of mitochondrial FAD levels explains this patient's riboflavin-responsive multiple acyl-CoA dehydrogenation disorder phenotype. (Pediatr Res 33: 129-135, 1993)
\end{abstract}

Received August 10. 1992: accepted October 8, 1992.

Correspondence: William J. Rhead, M.D., Ph.D., Division of Medical Genetics, Department of Pediatrics, University of lowa, Iowa City, IA 52242.

Supported by grants from the National Institutes of Health (DK-33289), National Foundation, March of Dimes (5-297 and 1-876). a Clinical Research Grant from the Muscular Dystrophy Association, and the Brent W. Brees/Dows Metabolic Research Fund.

'Portions of this work have heen published as non-peer reviewed symposia proceedings

\author{
Abbreviations \\ ADH, acyl-CoA dehydrogenase \\ ETF, electron transfer flavoprotein \\ FAD, flavin adenine dinucleotide \\ FMN, flavin mononucleotide \\ MAD, multiple acyl-CoA dehydrogenation disorder, severe \\ (S) and mild (M) variants \\ MCADH, medium chain acyl-CoA dehydrogenase \\ MEM, minimum essential medium \\ MeOH, methanol \\ aq, aqueous
}

The MAD are a group of human metabolic diseases affecting amino acid and fatty acid catabolism (1). Recognized variants include glutaric aciduria type Il or severe MAD (MAD:S), ethylmalonic aciduria or mild MAD (MAD:M), and riboflavin-responsive MAD (2-4). Most MAD:S patients present at birth with severe hypoglycemia. metabolic acidosis without ketosis, and a complex organic aciduria consisting of many fatty acid- and amino acid-derived metabolites, notably lactic, glutaric, ethylmalonic, adipic, and branched-chain organic acids; most die in the neonatal period (5). MAD:M patients usually present with less severe and varying clinical symptoms, including episodic hypoglycemia and acidosis, at ages ranging from infancy to early adulthood $(3,6)$; prominent urinary metabolites include ethylmalonic and adipic acids, similar to those found in MAD:S patients.

In these disorders, dehydrogenation of multiple acyl-CoA is blocked due to defective electron transport from the acyl-CoA to ubiquinone $\left(\mathrm{CoQ}_{10}\right)$ of the electron transport chain $(1.5)$. This sequence of mitochondrial oxidation-reduction reactions is mediated by a group of FAD-requiring enzymes: ADH. ETF, and ETF:ubiquinone oxidoreductase: all these enzymes ionically bind their cofactor FAD very tightly $\left(\mathrm{k}_{\mathrm{d}} \leq 2.4 \mu \mathrm{M} ; 1,7,8\right)$. In general, MAD patients display normal or near normal ADH activities (7-9). MAD:S patients have displayed very low activities of either ETF or ETF:ubiquinone oxidoreductase. whereas MAD:M patients have moderately deficient activities of one of these two enzymes $(7,8)$.

In contrast, the biochemical defects underlying the riboflavinresponsive MAD have not been identified. The first patient with this variant was described by Gregersen et al. (4) in 1982. This patient presented at age $2 \mathrm{y}, 8$ mo with lethargy, vomiting. hepatomegaly, hypoglycemia, and a mild metabolic acidosis. He excreted abnormal amounts of $\mathrm{C}_{6}-\mathrm{C}_{10}$-dicarboxylic acids, glutaric acid, ethylmalonic acid, and other fatty acid- and branchedchain amino acid-derived metabolites. He improved clinically and biochemically after supraphysiologic oral riboflavin supplementation was instituted. Although his fibroblasts oxidized 
$\left[{ }^{14} \mathrm{C}(\mathrm{U})\right]$ palmitate at $50 \%$ of control levels (4), fibroblast ADH activities. FMN. and FAD synthesis were normal after culture in supraphysiologic riboflavin concentrations (1). These observations tended to exclude a defect in cellular riboflavin uptake, FMN and/or FAD synthesis, or altered ADH apoenzymes as the primary abnormality in this patient. However, culture in vitamin-depleted medium is often necessary to demonstrate the enzymatic defect in fibroblasts from patients with vitamin responsive disorders, as culture in supraphysiologic vitamin concentrations can correct the metabolic block in vitro (10).

In preliminary studies, this patient's fibroblasts catabolized ${ }^{14} \mathrm{C}$-labeled octanoate and leucine normally after culture in riboflavin-supplemented media. However, after culture in riboflavindepleted media, his cells oxidized the same substrates much more poorly, confirming the riboflavin responsiveness of his metabolic defect in fibroblasts (11). We report here related cell oxidation studies in detail, as well as data arguing against defective FMN or FAD synthesis or altered FAD binding to mutant ADH or ETF apoenzymes. We suggest that defective maintenance of mitochondrial FAD levels explains his riboflavin-responsive phenotype.

\section{MATERIALS AND METHODS}

Substrates for intact cell oxidation studies were $\left[1-{ }^{14} \mathrm{C}\right]$ butyrate, -octanoate, and -palmitate: $\mathrm{L}-\left[2-{ }^{14} \mathrm{C}\right]$ leucine; $\left[1,4-{ }^{14} \mathrm{C}\right]$ succinate; and $\left[9,10(\mathrm{n})-{ }^{3} \mathrm{H}\right]$ - and $\left[15.16(\mathrm{n})-{ }^{-3} \mathrm{H}\right]$ palmitate from New England Nuclear (Cambridge, MA) and Amersham International (Arlington Heights. IL). D- $\left[2-{ }^{14} \mathrm{C}\right]$ riboflavin $(60 \mathrm{mCi} / \mathrm{mmol})$ was obtained from Amersham International (Arlington Heights, IL). Riboflavin, FMN, FAD, phenazine methosulfate, N-ethylmaleimide, and dichlorophenol indophenol were obtained from Sigma Chemical Co. (St. Louis, MO). [2,3- $\left.{ }^{3} \mathrm{H}\right]$ octanoyl-CoA was synthesized by the mixed anhydride method previously described (12); unlabeled octanoyl-CoA was obtained from P-L Biochemicals (Milwaukee. WI). Pure pig liver MCADH and ETF were gifts from Drs. Carole L. Hall, Georgia Institute of Technology (Atlanta. GA) and Colin Thorpe, University of Delaware (Wilmington, DE).

Skin fibroblasts were obtained from the patient (courtesy of Dr. N. Gregersen) and from five normal male infants. Cells were cultured in Eagle's MEM supplemented with $5 \%$ FCS, 2 mM glutamine, $140 \mu \mathrm{M}$ penicillin, and $86 \mu \mathrm{M}$ streptomycin. Medium was changed every week and fibroblasts were subcultured 1:4 every $2 \mathrm{wk}$. Fibroblasts of passage 8-18 were used in all assays.

Unless otherwise stated. patient and control fibroblasts were subcultured $2 \mathrm{wk}$ before the indicated assays into riboflavin-free MEM (KC Biologicals, Kansas City, KS) supplemented with 5\% or $10 \% \mathrm{Nu}$-Serum (Collaborative Research, Cambridge, MA), yielding final concentrations of $\leq 1.4$ or $\leq 2.8 \mu \mathrm{g}$ riboflavin/ $\mathrm{L}$, respectively. Two $\mathrm{mg}$ riboflavin/L was added to half the flasks (designated riboflavin-supplemented medium); no further riboflavin was added to the remaining flasks (designated riboflavindepleted medium). One wk before assay, cells were fed with either riboflavin-depleted or riboflavin-supplemented medium containing 5\% Nu-serum. In all experiments involving added riboflavin, cells were incubated in total darkness. Catabolism of ${ }^{14} \mathrm{C}$-labeled substrates and ${ }^{3} \mathrm{H}$-palmitates were assayed in intact cells using the methods previously described $(6,7,9)$. After culture in riboflavin-depleted media for $2 \mathrm{wk}$ and the 3-h oxidation experiments, cell viability was greater than $95 \%$ in both patient and control cells, as measured by trypan blue exclusion (data available on request).

Cellular riboflavin uptake and conversion to FMN and FAD were measured in whole cells by modifying Christensen's procedure (13): all manipulations were performed in reduced light. Fibroblasts from patient and control cells were grown to confluence in MEM supplemented with 5\% FCS. The medium was then replaced with riboflavin-free MEM without FCS containing ${ }^{14} \mathrm{C}$-riboflavin at the indicated concentrations; the flasks were incubated for the indicated intervals at $37^{\circ} \mathrm{C}$. Cells were harvested by trypsinization, centrifuged at $700 \times g$ for $10 \mathrm{~min}$, resuspended, and sonicated into $0.3 \mathrm{~mL} 5 \%$ aq $\mathrm{Na}_{2} \mathrm{HPO}_{4}, 0.6 \mathrm{~mL} \mathrm{MeOH}$. and $60 \mu \mathrm{L}$ carrier solution $(0.06 \mathrm{mg}$ each riboflavin, FMN, and FAD). MeOH precipitates proteins, releases FMN and FAD from proteins, and inactivates FMN and FAD hydrolyzing phosphatases active in cell homogenates (14-16). An aliquot was removed for protein determination and the remainder was incubated overnight at $4^{\circ} \mathrm{C}$ and centrifuged at $12000 \times g$ for $30 \mathrm{~min} ; 25$ $\mu \mathrm{L}$ of supernatants were used for separation of riboflavin. FMN. and FAD by thin-layer chromatography on Redi-coat silica gel glass plates (Supelco, Inc., Bellefonte. PA) with a solvent of $5 \%$ aq $\mathrm{Na}_{2} \mathrm{HPO}_{4}$, a running time of $40 \mathrm{~min}$, and a $15-\mathrm{cm}$ front. Characteristic $R_{f}$ values for this system were: riboflavin, 0.32: FMN, 0.45; and FAD, 0.61 (14). FMN and FAD spots were visualized under a UV lamp, scraped and collected into $10 \mathrm{~mL}$ of Scintiverse I (Fisher Scientific, Fairlawn, NJ), and counted in a Beckman scintillation counter (model LS8100; St. Louis, MO); recoveries of both from the plates were $75-80 \%$.

To uniformly radiolabel cellular flavin cofactor pools, patient and control cells were incubated in riboflavin-depleted medium for $24 \mathrm{~h}$ and then cultured in medium containing $31.4 \mu \mathrm{g}{ }^{14} \mathrm{C}-$ riboflavin/L for up to $3 \mathrm{wk}$. The cells were then cultured in riboflavin-depleted medium for 2 additional wk. Cellular ${ }^{14} \mathrm{C}-$ flavin contents were quantitated as described above at $2,5,8$, 14 , and $21 \mathrm{~d}$ during the uniform labeling phase and at $0,1,4,7$. and $14 \mathrm{~d}$ during the depletion phase.

Mitochondrial ${ }^{14} \mathrm{C}-\mathrm{FMN}$ and -FAD contents were also measured in patient and control cells grown in riboflavin-depleted medium for $2 \mathrm{wk}$. These flasks were then incubated in riboflavindepleted MEM with $4.4 \mu \mathrm{g}{ }^{14} \mathrm{C}$-riboflavin/L for 1 and $4 \mathrm{~h}$ or with $31.4 \mu \mathrm{g}{ }^{14} \mathrm{C}$-riboflavin/ $\mathrm{L}$ for $4 \mathrm{~h}$ at $37^{\circ} \mathrm{C}$. Cells were harvested by trypsinization (0.3-0.4 $\mathrm{g}$ wet weight/culture), and mitochondria were isolated as described previously, except that digitonin treatment was omitted $(7,17)$. This method yields fibroblast mitochondria purified 14-fold over cell homogenates and removes $80 \%$ of contaminating lysosomes (17). Mitochondrial pellets were suspended in $75 \mu \mathrm{L} 5 \%$ aq $\mathrm{Na}_{2} \mathrm{HPO}_{4}$ and an aliquot was assayed for glutamate dehydrogenase as described earlier (18). Proteins were precipitated with $0.15 \mathrm{~mL} \mathrm{MeOH}$ and ${ }^{14} \mathrm{C}$ FMN and -FAD quantitated as described in the preceding paragraph.

In cells incubated with $4.4 \mu \mathrm{g}{ }^{14} \mathrm{C}$-riboflavin/L for $4 \mathrm{~h}$, cystosolic fractions obtained during mitochondrial isolation were analyzed for ${ }^{14} \mathrm{C}-\mathrm{FMN}$ and -FAD content. The volume of each fraction was measured and an aliquot was removed for protein determination. To each volume of cytosolic fraction, 2 volumes $\mathrm{MeOH}$ and 0.2 volumes carrier solution $(0.1 \mathrm{mg}$ each $/ \mathrm{mL}$ riboflavin, FMN, and FAD) were added and the mixture was incubated in the dark at $4^{\circ} \mathrm{C}$ overnight. The precipitate was pelleted by centrifugation $(12000 \times g$ for $30 \mathrm{~min})$ and the supernatant evaporated to dryness on a rotary evaporator R-110 (Buchi/ Brinkmann Instruments, Slawil, Switzerland). The residue was redissolved in $3 \mathrm{~mL} \mathrm{H}_{2} \mathrm{O}$ and applied to a G-10 Sephadex column $(1 \times 35 \mathrm{~cm})$, and eluted with $\mathrm{H}_{2} \mathrm{O}$ at a flow rate of $3 \mathrm{~mL} / \mathrm{min}$. ${ }^{14} \mathrm{C}$-FMN and -FAD coeluted first, followed by riboflavin. Fractions were visualized with a UV lamp and aliquots of the ${ }^{14} \mathrm{C}$ FMN and -FAD fractions were counted; FMN and FAD recoveries were $75-80 \%$.

MCADH activity was measured in cell and mitochondrial sonic supernatants from patient and control fibroblasts using previously described tritium release and dye reduction assays. respectively (7). Concentrations of octanoyl-CoA and electron transfer agents, phenazine methosulfate and ETF, respectively, were chosen to maximize activities in these two assay systems $(7,17)$. The tritium release assay for the $\mathrm{ADH}$ is subject to a tritium isotope effect of 2 to 5 (17: other data not shown), which artifactually lowers cell supernatant activities relative to those predicted from the mitochondrial dye reduction assay. Supernatant aliquots from patient and control cells grown in ribofla- 
vin-depleted media were preincubated with FAD $(20 \mu \mathrm{M})$ for 5 min before assay and MCADH activity was then measured. ETF activity was measured in mitochondrial sonic supernatants from patient and control cells grown in riboflavin-supplemented and -depleted media using the optimized dye reduction method previously described (7).

Protein was determined by a fluorometric method (19). The estimate of variance used is the SEM. All $p$ values given were calculated by $t$ test, are two-tailed, and compare patient to appropriate control values, unless stated otherwise.

\section{RESULTS}

We have used ${ }^{14} \mathrm{C}$ - and ${ }^{3} \mathrm{H}$-substrate oxidation assays to quantitate the metabolic defect in other MAD patients $(6,9)$. After culture in standard media (Eagle's MEM) containing $0.1 \mathrm{mg}$ riboflavin/L, the patient's fibroblasts oxidized $\left[1-{ }^{14} \mathrm{C}\right]$ octanoate and -palmitate at 70 and $139 \%$ of control, respectively $(p>0.3$; data not shown). Inasmuch as total serum flavin concentrations are 3-fold lower $(\sim 0.03 \mathrm{mg} / \mathrm{L} ; 20)$ than the riboflavin concentration in MEM, we cultured patient and control cells in both riboflavin-supplemented $(2 \mathrm{mg} / \mathrm{L})$ and riboflavin-depleted media $(\leq 1.4 \mu \mathrm{g} / \mathrm{L})$ to uncover the patient's vitamin-responsive metabolic block. After culture in riboflavin-supplemented media, patient cells catabolized ${ }^{14} \mathrm{C}$ - and ${ }^{3} \mathrm{H}$-fatty acids and ${ }^{14} \mathrm{C}$ - and ${ }^{3} \mathrm{H}$ amino acids normally, at 65 to $130 \%$ of control (Table $1 ; p>$ 0.3 ). However, after culture in riboflavin-depleted media, the patient's cells oxidized ${ }^{14} \mathrm{C}$-butyrate, -octanoate, and -leucine much more poorly, at 21,20 , and $33 \%$ of control, respectively $(p<0.05)$, revealing the riboflavin-responsive nature of his metabolic defect. After culture in riboflavin-depleted media, [1$\left.{ }^{14} \mathrm{C}\right]-,\left[9,10(\mathrm{n})-{ }^{3} \mathrm{H}\right]-$ and $\left[15,16(\mathrm{n}){ }_{-}^{3} \mathrm{H}\right]$ palmitate oxidation in all cells fell to 3 to $28 \%$ of the values observed after culture in 2.0 $\mathrm{mg}$ riboflavin/L, obscuring any riboflavin-dependent decrease in the patient. $\left[1,4,{ }^{14} \mathrm{C}\right]$ succinate oxidation was normal in both patient and control cells cultured under all conditions, suggesting that the patient's riboflavin-responsive metabolic defect does not involve the flavoproteins of the mitochondrial electron transport chain.

Because culture in riboflavin-depleted media unmasked the patient's metabolic defect, we measured cellular riboflavin uptake and conversion to FMN and FAD in patient and control fibroblasts incubated with $3,31.4$, and $100 \mu \mathrm{g}{ }^{14} \mathrm{C}$-riboflavin/L, concentrations ranging from 10 to $300 \%$ of mean plasma flavin levels in man (20). The patient's cells synthesized ${ }^{14} \mathrm{C}$-FMN and -FAD normally after $4 \mathrm{~h}$ in all three concentrations and after 1 and $10 \mathrm{~h}$ in $31.4 \mu \mathrm{g}{ }^{14} \mathrm{C}$-riboflavin/L (Table 2). In all cells, incubation in $31.4 \mu \mathrm{g}{ }^{14} \mathrm{C}$-riboflavin/L raised cellular ${ }^{14} \mathrm{C}$-flavin contents 3- to 5-fold over those found after culture in $3 \mu \mathrm{g}{ }^{14} \mathrm{C}$ riboflavin/L. However, incubation with $100 \mu \mathrm{g}{ }^{14} \mathrm{C}$-riboflavin/L did not further raise cellular ${ }^{14} \mathrm{C}$-flavin levels, suggesting that $31.4 \mu \mathrm{g} / \mathrm{L}$ was saturating for cellular riboflavin uptake and flavin cofactor synthesis. In other experiments, we also measured cytoplasmic levels of ${ }^{14} \mathrm{C}$-flavins in cells grown in riboflavin-depleted media and incubated with low ${ }^{14} \mathrm{C}$-riboflavin $(4.4 \mu \mathrm{g} / \mathrm{L})$ for $4 \mathrm{~h}$; the sum of ${ }^{14} \mathrm{C}-\mathrm{FMN}$ and -FAD was similar in both control and patient cytoplasm (3.6 \pm 0.43 and $2.8 \pm 0.37 \mathrm{pmol} /$ mg protein, respectively; $n=3, p>0.4$ ), further arguing against defective FMN and FAD synthesis in the patient's cells.

Although these short-term radiolabeling experiments demonstrated no defects in ${ }^{14} \mathrm{C}$-FMN and -FAD synthesis in the patient's cells, the amounts of ${ }^{14} \mathrm{C}$-flavins synthesized may not accurately reflect the steady state sizes of cellular flavin cofactor pools. For this reason, we uniformly labeled cellular ${ }^{14} \mathrm{C}$-flavins by culturing patient and control cells in $31.4 \mu \mathrm{g}{ }^{14} \mathrm{C}$-riboflavin/L for $3 \mathrm{wk}$. After 2 wk, cellular ${ }^{14} \mathrm{C}$-FMN and -FAD specific radioactivities had plateaued and did not increase further at 3 wk (Table 3; other data not shown). Interestingly, control ${ }^{14} \mathrm{C}-\mathrm{FAD}$ specific radioactivities after $10 \mathrm{~h}$ of culture were $47 \%$ of those found after $2 \mathrm{wk}$ of uniform labeling (21.2 and $45.0 \mathrm{pmol} / \mathrm{mg} / \mathrm{protein}$.

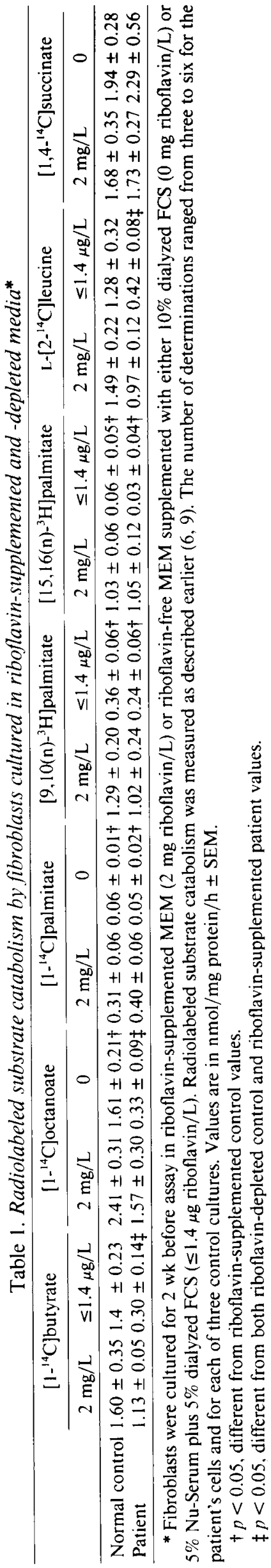


Table 2. $D-22-{ }^{14} \mathrm{C} /$ riboflavin incorporation into ${ }^{14} \mathrm{C}-\mathrm{FMN}$ and ${ }^{14} \mathrm{C}-\mathrm{FAD}$ in intact fibroblasts ${ }^{*}$

\begin{tabular}{|c|c|c|c|c|c|c|c|}
\hline \multirow[b]{2}{*}{ Culture } & \multirow{2}{*}{$\begin{array}{c}\text { Length of } \\
\text { incubation }(\mathrm{h})\end{array}$} & \multicolumn{3}{|c|}{${ }^{14} \mathrm{C}-\mathrm{FMN}$} & \multicolumn{3}{|c|}{${ }^{14} \mathrm{C}-\mathrm{FAD}$} \\
\hline & & $3.0 \mu \mathrm{g} / \mathrm{L}$ & $31.4 \mu \mathrm{g} / \mathrm{L}$ & $100 \mu \mathrm{g} / \mathrm{L}$ & $3.0 \mu \mathrm{g} / \mathrm{L}$ & $31.4 \mu \mathrm{g} / \mathrm{L}$ & $100 \mu \mathrm{g} / \mathrm{L}$ \\
\hline Normal control & $\begin{array}{r}1 \\
4 \\
10\end{array}$ & $\begin{array}{c}\text { ND } \\
0.67 \pm 0.06 \\
\text { ND }\end{array}$ & $\begin{array}{l}4.02 \pm 0.53 \\
3.63 \pm 0.31 \\
5.98 \pm 0.95\end{array}$ & $\begin{array}{c}\text { ND } \\
3.76 \pm 0.62 \\
\text { ND }\end{array}$ & $\begin{array}{c}\text { ND } \\
2.77 \pm 0.44 \\
\text { ND }\end{array}$ & $\begin{array}{r}5.4 \pm 0.55 \\
10.7 \pm 0.45 \\
23.5 \pm 2.21\end{array}$ & $\begin{array}{c}\mathrm{ND} \\
9.6 \pm 2.29 \\
\mathrm{ND}\end{array}$ \\
\hline Patient & $\begin{array}{r}1 \\
4 \\
10\end{array}$ & $\begin{array}{c}\text { ND } \\
1.18 \pm 0.30 \\
\text { ND }\end{array}$ & $\begin{array}{l}2.07 \pm 0.43 \\
4.92 \pm 0.72 \\
4.89 \pm 0.38\end{array}$ & $\begin{array}{c}\text { ND } \\
4.91 \pm 0.77 \\
\text { ND }\end{array}$ & $\begin{array}{c}N D \\
3.86 \pm 0.83 \\
N D\end{array}$ & $\begin{array}{r}4.8 \pm 0.51 \\
14.5 \pm 1.32 \\
21.2 \pm 1.15\end{array}$ & $\begin{array}{c}\text { ND } \\
14.1 \pm 1.81 \\
\text { ND }\end{array}$ \\
\hline
\end{tabular}

${ }^{*}$ Fibroblasts were incubated in $\mathrm{D}-\left[2-{ }^{14} \mathrm{C}\right]$ riboflavin at the indicated concentrations and intervals. ${ }^{14} \mathrm{C}-\mathrm{FMN}$ and $-\mathrm{FAD}$ were measured as described in the text. The results of four to eight separate experiments were combined. Values are in $\mathrm{pmol} / \mathrm{mg}$ protein \pm SEM. ND. not determined.

Table 3. Uniform radiolabeling and depletion of ${ }^{14} \mathrm{C}-\mathrm{FAD}$ pools in intact fibroblast. $*$

\begin{tabular}{|c|c|c|c|c|c|c|c|}
\hline Culture & \multicolumn{3}{|c|}{ Days of radiolabeling } & \multicolumn{4}{|c|}{ Days of depletion } \\
\hline Normal control & $25.8 \pm 3.3$ & $32.3 \pm 3.2$ & $45.0 \pm 8.0$ & $21.9 \pm 3.2$ & $17.0 \pm 2.0$ & $10.8 \pm 1.6$ & $5.7 \pm 1.2$ \\
\hline
\end{tabular}

* Patient and control cells were cultured in $31.4 \mu \mathrm{g} \mathrm{D}-\left[2-{ }^{14} \mathrm{C}\right]$ riboflavin/L before culture in riboflavin-depleted medium $(\leq 1.4 \mu \mathrm{g}$ riboflavin/L) for the indicated intervals. Cellular ${ }^{14} \mathrm{C}$-FAD levels were measured as described in the text. The number of determinations ranged from three to four for the patient's cells and each of three control cultures. Values are in pmol/mg protein \pm SEM.

+ One-tail $p<0.03$.

respectively: $n \geq 3$ ), suggesting that a substantial proportion of cellular flavin pools turn over rapidly. These uniformly labeled cells were then cultured in riboflavin-depleted medium for $2 \mathrm{wk}$. with intact cell ${ }^{14} \mathrm{C}$-flavin levels determined at intervals during the depletion phase. After 4, 7, and $14 \mathrm{~d}$ of riboflavin depletion, patient ${ }^{14} \mathrm{C}$-FAD cell contents were 48,37 , and $23 \%$ of control, respectively (one-tail $p \leq 0.03$ for all). Patient ${ }^{14} \mathrm{C}$-FMN levels were 15 and $28 \%$ of control after 7 and $14 \mathrm{~d}$ of depletion. respectively (one-tail $p<0.05$ : data available on request). Thus, flavin cofactor homeostasis appears profoundly altered in this patient's cells when they are cultured under conditions of riboflavin deprivation.

Because most cell flavins are contained in the mitochondria, we then measured mitochondrial ${ }^{14} \mathrm{C}$-FMN and -FAD levels in cells incubated with ${ }^{14} \mathrm{C}$-riboflavin at varying concentrations and intervals. After incubations in $4.4 \mu \mathrm{g}{ }^{14} \mathrm{C}$-riboflavin/L, the patient's mitochondrial ${ }^{14} \mathrm{C}$-FMN contents rose between 1 and $4 \mathrm{~h}$ but remained lower than control at both times ( 44 and $54 \%$ of control, respectively: Table 4). After incubation with $4.4 \mu \mathrm{g}{ }^{14} \mathrm{C}$ riboflavin/L. the patient's ${ }^{14} \mathrm{C}$-FAD content was $51 \%$ of control at $1 \mathrm{~h}(p<0.05)$. After $4 \mathrm{~h}$, control mitochondrial ${ }^{14} \mathrm{C}-\mathrm{FAD}$ content had increased significantly $(p=0.05$ compared with 1 $\mathrm{h}$ control), whereas the patient's ${ }^{14} \mathrm{C}$-FAD content did not change and was $29 \%$ of control $(p<0.05)$.

After $4 \mathrm{~h}$ of incubation with $31.4 \mu \mathrm{g}{ }^{14} \mathrm{C}$-riboflavin/L, a high physiologic concentration, control and patient cellular ${ }^{14} \mathrm{C}-\mathrm{FAD}$ contents had increased to comparable high values (Table 2) and the patient's mitochondria then contained normal amounts of ${ }^{14} \mathrm{C}$-FAD (Table 4). Control mitochondrial ${ }^{14} \mathrm{C}$-FAD content was similar to that found after culture in low riboflavin concentrations, whereas the patient's ${ }^{14} \mathrm{C}$-FAD content had risen significantly $(p<0.01)$. Analogously, patient mitochondrial ${ }^{14} \mathrm{C}-\mathrm{FMN}$ content rose after incubation in high ${ }^{14} \mathrm{C}$-riboflavin for $4 \mathrm{~h}$. whereas control ${ }^{14} \mathrm{C}$-FMN content did not change. These observations suggest that control mitochondrial ${ }^{14} \mathrm{C}$-flavin contents reached maximal values after incubation for $4 \mathrm{~h}$ in low extracellular ${ }^{14} \mathrm{C}$-riboflavin concentrations $(4.4 \mu \mathrm{g} / \mathrm{L})$. whereas the patient's cells required incubation in 7-fold higher extracellular concentrations to attain similar levels. Activity of glutamate dehydrogenase, a mitochondrial matrix marker enzyme, was similar in both control and patient mitochondrial preparations $(2.1 \pm 0.28$ and $1.9 \pm 0.42 \mathrm{nmol} / \mathrm{mg}$ protein $/ \mathrm{min}$. respectively: $p>0.6$ ). suggesting that the observed differences in flavin content did not result from differing purity of mitochondria from control and patient's cells.

The finding that riboflavin depletion profoundly decreased ${ }^{14} \mathrm{C}$-octanoate oxidation in patient fibroblasts. but not in control cells, could be explained by aberrant FAD binding to a mutant MCADH, a rate-limiting enzyme of $\beta$-oxidation catalyzing the initial dehydrogenation step of $\mathrm{C}_{6}-\mathrm{C}_{12}$ fatty acyl-CoA (1). After culture in riboflavin-supplemented media, patient MCADH activity was $69 \%$ of control in cell sonic supernatants when measured with a tritium release assay ( $p>0.2$; data available on request). After culture in riboflavin-depleted media, both control and patient MCADH activities fell dramatically and remained identical. When both control and patient cell sonic supernatants were preincubated with $20 \mu \mathrm{M}$ FAD before assay, no restoration of activity was seen, suggesting loss of MCADH apoenzyme

Table 4. D- $\left[2-{ }^{14} \mathrm{C} /\right.$ riboflavin incorporation into mitochondrial ${ }^{14} \mathrm{C}-F M N$ and ${ }^{14} \mathrm{C}-F A D^{*}$

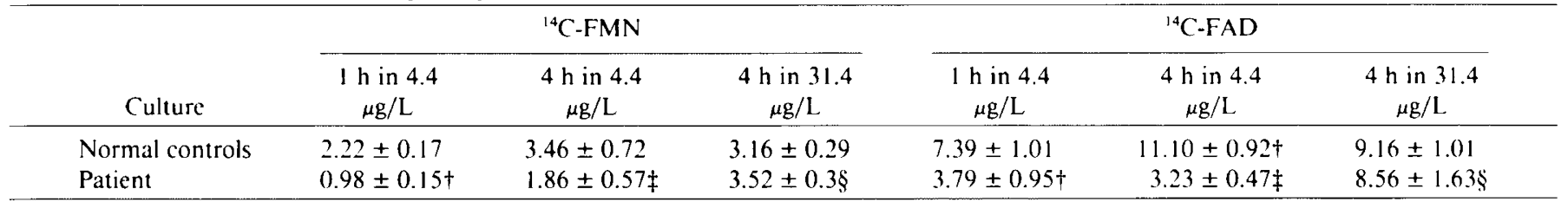

${ }^{*}$ Fibroblasts were cultured in riboflavin-depleted media for $2 \mathrm{wk}$ before assay and then incubated in $\left[2-{ }^{14} \mathrm{C}\right]$ riboflavin for 1 or $4 \mathrm{~h}$. Mitochondria were isolated and ${ }^{14} \mathrm{C}$-FMN and ${ }^{14} \mathrm{C}$-FAD contents were measured. The number of determinations ranged from three to eight for the patient's cells and for each of four control cultures. Values are in $\mathrm{pmol} / \mathrm{mg}$ protein $\pm \mathrm{SEM}$.

$+p<0.05$. different from 1 -h control value.

$\ddagger p<0.01$, different from 4 -h $4.4 \mu \mathrm{g} / \mathrm{L}$ control value.

$\S p<0.01$, different from $4-\mathrm{h} 4.4 \mu \mathrm{g} / \mathrm{L}$ patient value. 
during sonication of riboflavin-depleted cells. In support of this hypothesis, the patient's MCADH activities in mitochondrial matrix preparations were 72 and $70 \%$ of control after culture in riboflavin-supplemented and -depleted media, respectively, as measured with a dye reduction assay; activities did not increase upon incubation with $20 \mu \mathrm{M}$ FAD ( $p>0.2$; data available on request). These observations suggest that a lowered affinity of MCADH for FAD does not explain the patient's riboflavinresponsive defect in ${ }^{14} \mathrm{C}$-octanoate oxidation.

Because ETF catalyzes the initial step in electron transfer from the six reduced $\mathrm{ADH}$ to the electron transport chain, a mutant ETF apoenzyme with decreased affinity for FAD could explain this patient's riboflavin-responsive phenotype. However, after culture in riboflavin-depleted media, ETF activities were identical in both control and patient cell sonic supernatants $(p>0.8$; data available on request). Because reconstitution of ETF holoenzyme from cystolic FAD and mitochondrial matrix apoenzyme could explain these latter results, we also assayed ETF in mitochondrial matrix fractions. In riboflavin-supplemented cells, the patient's ETF activity was $75 \%$ of control (Table $5 ; p>0.2$ ); however, after culture in riboflavin-depleted medium, the patient's ETF activity fell to $59 \%$ of control (one-tail $p<0.05$ ), compatible with low mitochondrial FAD content lowering ETF activity. Preincubation with $20 \mu \mathrm{M}$ FAD raised the patient's ETF activity to $76 \%$ of control ( $p>0.2)$, comparable to the values in riboflavin-supplemented cells and consistent with reconstitution of active ETF holoenzyme.

\section{DISCUSSION}

This patient excreted metabolites consistent with the generalized defect in mitochondrial acyl-CoA dehydrogenation characteristic of the MAD $(1,5)$. His marked clinical and biochemical responses to supraphysiologic riboflavin doses suggested that he was a riboflavin-responsive MAD variant (4). Because MAD fibroblasts oxidize ${ }^{14} \mathrm{C}$-labeled fatty and amino acids poorly, cell oxidation studies were performed. After culture in media containing routine or high riboflavin concentrations $(0.1$ or $2.0 \mathrm{mg} /$ $\mathrm{L})$, his cells oxidized ${ }^{14} \mathrm{C}$-substrates normally (11). However, in other vitamin-responsive metabolic disorders, growth in supraphysiologic vitamin concentrations corrects the metabolic defect in cultured cells (10). Therefore, we cultured cells in subphysiologic riboflavin concentrations $(\leq 1.4 \mu \mathrm{g} / \mathrm{L} ; 20)$ and found that the patient's fibroblasts did not catabolize multiple ${ }^{14} \mathrm{C}$-substrates as well as did normal cells cultured in the same media or as did his cells cultured in riboflavin-supplemented media. Under these culture conditions, oxidation of $\left[1-{ }^{14} \mathrm{C}\right]-,\left[9,10(\mathrm{n})-{ }^{3} \mathrm{H}\right]-$, and $\left[15,16(\mathrm{n})-{ }^{3} \mathrm{H}\right]$ palmitates fell dramatically in both control and patient cells. Some aspect of long-chain fatty acid oxidation in fibroblasts seems especially sensitive to riboflavin depletion. Although the available data cannot explain these observations (21), these intact cell oxidation assays cannot distinguish between the primary and secondary effects of riboflavin deprivation on palmitate oxidation.

Table 5. ETF activity in fibroblasts cultured in presence and absence of riboflavin*

Riboflavin concentration and FAD preincubation

\begin{tabular}{lccc}
\cline { 2 - 4 } \multicolumn{1}{c}{ Culture } & $\begin{array}{c}2 \mathrm{mg} / \mathrm{L} \\
\text { None }\end{array}$ & $\begin{array}{c}\leq 1.4 \mu \mathrm{g} / \mathrm{L} \\
\text { None }\end{array}$ & $\begin{array}{c}\leq 1.4 \mu \mathrm{g} / \mathrm{L} \\
20 \mu \mathrm{M}\end{array}$ \\
\hline Normal controls & $478 \pm 43$ & $482 \pm 12$ & $593 \pm 84$ \\
Patient & $360 \pm 65$ & $283 \pm 60 \dagger$ & $451 \pm 43$
\end{tabular}

* Fibroblasts were cultured in riboflavin-supplemented or -depleted media for 2 wk before assay. ETF was measured in mitochondrial supernatants as described in the text. with or without FAD preincubation for $5 \mathrm{~min}$. The number of determinations ranged from two to five. Values are in $\mathrm{pmol} / \mathrm{mg}$ protein $/ \mathrm{min} \pm \mathrm{SEM}$.

+ One-tail $p<0.05$, different from control.
Normal $\left[1,4-{ }^{14} \mathrm{C}\right]$ succinate oxidation in riboflavin-depleted patient cells implied normal function of both succinate dehydrogenase, a FAD-requiring enzyme of the inner mitochondrial membrane, and the main electron transport chain from coenzyme $\mathrm{Q}$ to cytochrome $a a_{3}(1,3,6,9,11)$. Analogously, liver mitochondria from weanling rats fed a riboflavin-depleted diet showed dramatic decreases in fatty acid oxidation and in $\mathrm{ADH}$ activities when compared with rats fed a normal diet; succinate oxidation was much less severely affected (21). In our experiments, the degree of riboflavin depletion sufficed to unmask the patient's vitamin-responsive defect without uniformly altering acyl-CoA metabolism in control cells. Normal cell survival in our experiments suggested that riboflavin depletion did not affect viability of either patient or controls. Cells from both nonriboflavin-responsive mild MAD patient 840 and MCADH-deficient patient SG $(6,7)$ oxidized $\left[1-{ }^{14} \mathrm{C}\right]$ octanoate identically after culture in media containing $\leq 1.4 \mu \mathrm{g} / \mathrm{L}, 0.1 \mathrm{mg} / \mathrm{L}$, and $2.0 \mathrm{mg}$ riboflavin/L (data available upon request). Thus, worsening of the oxidative defect upon riboflavin depletion is not a general phenomenon in cells from patients with $\beta$-oxidation defects.

Defects in one of many systems could explain this patient's riboflavin-responsive metabolic disorder: cellular riboflavin uptake, cytosolic FMN/FAD synthesis, mitochondrial FMN/FAD uptake or homeostasis, or FAD binding to $\mathrm{ADH}$, ETF, or ETF:ubiquinone oxidoreductase apoenzymes. Information is available concerning several of these steps (22). Although there is a high-affinity riboflavin-binding protein in the maternal circulation of ovulating birds, there is no known specific intra- or extracellular riboflavin transport protein in mammals (23). Riboflavin transport into the cell is energy-dependent and involves metabolic trapping of riboflavin as FMN (24). FAD synthesis requires two enzymes located in the cytosol, riboflavin kinase converting riboflavin to FMN and FAD pyrophosphorylase synthesizing FAD from FMN $(22,24)$. Currently, the mechanisms of FAD transport into mitochondria and/or maintenance of matrix FAD levels are unknown. FAD is bound ionically to the $\mathrm{ADH}, \mathrm{ETF}$, and ETF:ubiquinone oxidoreductase $(25,26)$.

To study cellular riboflavin uptake and FMN/FAD synthesis, cells were incubated with ${ }^{14} \mathrm{C}$-riboflavin and ${ }^{14} \mathrm{C}$-FMN and -FAD levels measured. Total serum flavin concentration is 26-37 $\mu \mathrm{g} / \mathrm{L}$ in man, with $18-30 \mu \mathrm{g} / \mathrm{L}$ representing FAD (20). For these studies, we used a 30 -fold range of ${ }^{14} \mathrm{C}$-riboflavin concentrations, including a subphysiologic level $(3 \mu \mathrm{g} / \mathrm{L})$, because the metabolic defect in intact fibroblasts was most pronounced in cells cultured in riboflavin-depleted medium. We found that whole cell and cystosolic ${ }^{14} \mathrm{C}$-FMN and -FAD contents were similar in both control and patient cells under all study conditions. Using a different separation system and 60- to 2000-fold higher concentrations of ${ }^{14} \mathrm{C}$-riboflavin, Gregersen et al. (11) also found normal cellular riboflavin uptake and incorporation into ${ }^{14} \mathrm{C}-\mathrm{FMN}$ and -FAD in this patient. Our present results further suggest that deficient cellular riboflavin uptake and synthesis of FMN and FAD are not the primary biochemical defects in this patient.

Uniform labeling of cellular flavin pools with ${ }^{14} \mathrm{C}$-riboflavin revealed normal kinetics and levels of ${ }^{14} \mathrm{C}$-flavin accumulations in the patient's cells cultured in physiologic ${ }^{14} \mathrm{C}$-riboflavin concentrations, which is consistent with the data from the shortterm ${ }^{14} \mathrm{C}$-radiolabeling experiments. However, the patient's cells did not maintain flavin cofactor pools when normally depleted of riboflavin for an extended period. These observations are consistent with some generalized biochemical defect altering overall cellular flavin cofactor biosynthesis, metabolism, and homeostasis, rather than an isolated defect involving only a single mutant apoflavoenzyme with an altered affinity for FAD. This interpretation is consistent with our data on mitochondrial ${ }^{14} \mathrm{C}$ FAD contents, MCADH, and ETF activities discussed below.

To measure mitochondrial FAD content, fibroblasts were incubated with ${ }^{14} \mathrm{C}$-riboflavin, the mitochondria isolated, and ${ }^{14} \mathrm{C}$ FMN and -FAD contents measured. ${ }^{14} \mathrm{C}-\mathrm{FMN}$ contents were $\leq 54 \%$ of control after culture in low ${ }^{14} \mathrm{C}$-riboflavin and increased 
to normal in high ${ }^{14} \mathrm{C}$-riboflavin. After incubation with low ${ }^{14} \mathrm{C}$ riboflavin, the patient's ${ }^{14} \mathrm{C}-\mathrm{FAD}$ content did not increase from 1 to $4 \mathrm{~h}$ and was $29 \%$ of control at $4 \mathrm{~h}$, whereas control mitochondrial ${ }^{14} \mathrm{C}$-FAD contents rose significantly during the same time interval. After a 4-h incubation with high physiologic levels of ${ }^{14} \mathrm{C}$-riboflavin $(31.4 \mu \mathrm{g} / \mathrm{L})$, the patient's ${ }^{14} \mathrm{C}-\mathrm{FAD}$ content rose into the normal range, whereas control ${ }^{14} \mathrm{C}$-FAD contents did not increase. Thus, control mitochondrial FAD contents apparently attain steady state at even very low extracellular riboflavin concentrations $(4.4 \mu \mathrm{g} / \mathrm{L}=12 \mathrm{nM})$, whereas the patient's cells require much higher extracellular concentrations to reach control FAD levels. These observations are consistent with the vitamin responsiveness of his metabolic block $(4,11)$. Inasmuch as we found normal whole cell and cytosolic ${ }^{14} \mathrm{C}-\mathrm{FMN}$ and -FAD contents in the patient, this result suggests defective maintenance of mitochondrial FMN and FAD levels in his cells.

We also studied two enzymes of $\beta$-oxidation for defective FAD binding to altered apoenzymes. MCADH activities in both control and patient cells fell to similar low levels after culture in riboflavin-depleted media; preincubation of these control and patient cell sonic supernatants with FAD did not restore MCADH activity. Several mechanisms could explain loss of apoMCADH after growth in riboflavin-depleted medium: increased turnover of unstable apo-MCADH without FAD in vivo or loss of apo-MCADH during preparation of cell sonic supernatants. Hoppel et al. (27) and Sakurai et al. (21) found decreased MCADH activities in liver mitochondria from rats fed a riboflavin-deficient diet; the latter authors reconstituted holo-MCADH after incubation of their preparations with FAD, which is consistent with preservation of functional apoenzymes. Goodman (28) found that glutaryl-CoA dehydrogenase activity decreased in riboflavin-deficient rats and was more thermolabile when FAD was absent, suggesting stabilization of the apoenzyme by FAD. Relative destabilization of apo-MCADH in our control cells during riboflavin-deprivation probably leads to apoenzyme loss during cell sonication, obscuring any preferential loss of apoMCADH in the patient's cells. Culture in riboflavin-depleted media did not lower MCADH activity in either control or patient mitochondrial matrix preparations, supporting this hypothesis.

We found no ETF activity differences between patient or control cell sonic supernatants after culture in riboflavin-depleted medium. We postulated that cell sonication mixed mitochondrial apo-ETF with cytosolic FAD, reconstituted ETF holoenzyme, and obscured any ETF activity reduction caused by reduced mitochondrial FAD content in the patient. This possibility is rendered plausible by our finding mildly reduced mitochondrial matrix ETF activity in riboflavin-depleted patient's cells, which was reversed by FAD addition. Culture in riboflavin-depleted medium should not produce ETF apoenzyme loss per se, inasmuch as Sakurai et al. (21) found no differences in ETF activity in liver mitochondria from rats fed riboflavin-depleted or -supplemented diets. Because riboflavin depletion apparently lowered the patient's ETF activity more than his MCADH activity and because ETF appears rate-limiting for turnover of all the $\operatorname{ADH}(1,7,8)$, decreased ETF activity could help explain his impaired mitochondrial acyl-CoA dehydrogenation (11).

Assaying MCADH and ETF in mitochondria from the patient's cells cultured in riboflavin-depleted media did not demonstrate the large activity decreases that might be expected from the observed decreases in cellular and mitochondrial ${ }^{14} \mathrm{C}-\mathrm{FAD}$ levels. Our mitochondrial matrix fractions, although purified 10to 15 -fold (17), may contain trace amounts of cytoplasmic FAD, partially reconstituting the active holoenzymes. In contrast, the lack of large activity decreases under these conditions also argues against the existence of mutant MCADH or ETF apoenzymes with greatly decreased FAD affinities, inasmuch as extremely high cofactor concentrations are generally required to restore activity in such circumstances (10).

We suggest that this patient's riboflavin-responsive MAD phenotype results from a defect in maintaining mitochondrial FAD levels, presumably lowering the overall efficiency of acyl-CoA dehydrogenation and $\beta$-oxidation. Our data argue against defects in cytoplasmic FMN and FAD synthesis; other possible explanations include reduced mitochondrial FMN or FAD uptake, intramitochondrial conversion of FMN to FAD, or synthesis and turnover of a mitochondrial flavoprotein essential to maintain mitochondrial FAD levels. Because we postulate that this patient has an inherited disorder involving a single gene product, the last possibility seems unlikely, inasmuch as at least 10 different flavoenzymes are present in the mitochondrial inner membrane and matrix compartments. It seems improbable that only one plays a central role in maintenance of mitochondrial FAD levels. Additional studies of the other possibilities are clearly warranted and are in progress in our laboratory.

Acknowledgments. The authors thank Drs. C. Hall and C. Thorpe for the kind gifts of MCADH and ETF, and K. Crowe, L. Abel, and N. Jausel for clerical assistance. We thank Drs. N. Gregersen, E. Christensen, and S. Kolvraa for kindly providing the fibroblasts from this patient and for thier many useful suggestions and discussions.

\section{REFERENCES}

1. Gregersen N 1985 The acyl-CoA dehydrogenation deficiencies. Scand J Clin Invest 45(suppl 174): 1-60

2. Przyrembel $H$, Wendel $U$, Becker $K$. Bremer $H$, Bruinvis L, Ketting D Wadman S 1976 Glutaric aciduria type II: report on a previously undescribed metabolic disorder. Clin Chim Acta 66:227-239

3. Mantagos S, Genel M, Tanaka K 1979 Ethylmalonic-adipic aciduria. J Clin Invest 64:1580-1589

4. Gregersen N, Wintzensen H, Kolvraa S, Christensen E. Christensen M. Brandt $\mathrm{N}$, Rasmussen $\mathrm{K} 1982 \mathrm{C}_{6}-\mathrm{C}_{10}$-dicarboxylic aciduria: investigations of a patient with riboflavin responsive multiple acyl-CoA dehydrogenation defects. Pediatr Res 16:861-868

5. Frerman F, Goodman SI 1989 Glutaric acidemia type II and defects of the mitochondrial respiratory chain. In: Scriver CR, Beaudet AL, Sly WS, Vale D (eds) The Metabolic Basis of Inherited Disease. McGraw Hill. St. Louis, pp $915-931$

6. Rhead W, Wolff J, Lipson M, Falace P, Desai N, Fritchman K, Moon A, Sweetman L 1987 Clinical and biochemical variation and family studies in the multiple acyl-CoA dehydrogenation disorders. Pediatr Res 21:371-376

7. Amendt B, Rhead W 1986 The multiple acyl-coenzyme A dehydrogenation disorders, glutaric aciduria type II and ethylmalonic-adipic aciduria. J Clin Invest 78:205-213

8. Frerman F, Goodman S 1985 Deficiency of electron transfer flavoprotein or electron transfer flavoprotein:ubiquinone oxidoreductase in glutaric aciduria type II fibroblasts. Proc Natl Acad Sci USA 82:4517-4520

9. Rhead W, Mantagos S, Tanaka K 1980 Glutaric aciduria type II: in vitro studies on substrate oxidation, acyl-CoA dehydrogenases and electron transferring flavoprotein using cultured skin fibroblasts. Pediatr Res 14:13391342

10. Lipson MH, Kraus J, Rosenberg LE 1980 Affinity of cystathionine $\beta$-synthase for pyridoxal-5'-phosphate in cultured cells. J Clin Invest 66:188-193

11. Gregersen N. Rhead W. Christensen E 1989 Riboflavin responsive glutaric aciduria type II. In: Clinical, Biochemical and Molecular Aspects of Fatty Acid Oxidation. Alan R Liss, New York, pp 477-494

12. Rhead W, Hall C, Tanaka K 1981 Novel tritium release assays for isovaleryl CoA and butyryl CoA dehydrogenases. J Biol Chem 256:1616-1624

13. Christensen E, Kolvraa S, Gregersen N 1984 Glutaric aciduria type II: evidence for a defect related to the electron transfer flavoprotein or its dehydrogenase. Pediatr Res 18:663-667

14. Okuda J. Nagamine J, Ukumura M. Yagi K 1978 Metabolism of injected flavins studied by using double-labeled $\left[{ }^{14} \mathrm{C}\right]$ flavin adenine dinucleotide and $\left[{ }^{14} \mathrm{C},{ }^{32} \mathrm{P}\right]$ flavin mononucleotide. J Nutr Sci Vitaminol 24:505-510

15. Fazekas A. Sandor T 1973 Studies on the biosynthesis of flavin nucleotides from $2-{ }^{14} \mathrm{C}$-riboflavin by rat liver and kidney. Can J Biochem 51:772-782

16. Fazekas A, Kokai K 1979 Extraction, purification, and separation of tissue flavins for spectrophotometric determination. Methods Enzymol 18B:385398

17. Rhead W, Tanaka K 1980 Demonstration of a specific isovaleryl CoA dehydrogenase deficiency in fibroblasts from patients with isovaleric acidemia. Proc Natl Acad Sci USA 77:580-58.3

18. Strecker H 1955 L-Glutamate dehydrogenase from liver. Methods Enzymol 2:220-225

19. Bohlen P, Stein S, Dairman W, Udenfriend S 1973 Fluorometric assay of proteins in the nanogram range. Arch Biochem Biophys 155:213-220

20. Burch HB, Bessey O. Lowry O 1948 Fluorometric measurements of riboflavin and its natural derivatives in small quantities of blood serum and cells. $J$ Biol Chem 175:457-470

21. Sakurai T. Miyazawa S. Furuta S, Hashimoto T 1982 Riboflavin deficiency and $\beta$-oxidation systems in rat liver. Lipids 17:598-604 
22. McCormick D 1975 Metabolism of riboflavin. In: Rivlin RS (ed) Riboflavin. Plenum Press, New York, pp 153-198

23. White HB, Merrill AH 1988 Riboflavin-binding proteins. Ann Rev Nutr 8:279299

24. Aw T, Jones D. McCormick D 1983 Uptake of riboflavin by isolated rat liver cells. J Nutr 1 13:1249-1254

25. Hall CL. Kamin HD 1975 The purification and some properties of electron transfer flavoprotein and general acyl-coenzyme A dehydrogenase from pig liver mitochondria. J Biol Chem 250:3476-3486
26. Ruzicka R, Beinert H 1977 A new iron-sulfur flavoprotein of the respiratory chain: a component of fatty acid $\beta$-oxidation pathway. J Biol Chem 252:8440-8445

27. Hoppel C. DeMarco J. Tandler B 1979 Riboflavin and rat hepatic cell structure and function: mitochondrial oxidative metabolism in deficiency states. $\mathrm{J}$ Biol Chem 254:4164-4170

28. Goodman S 1981 Organic aciduria in the riboflavin-deficient rat. Am J Clin Nutr 34:2434-2437

\section{Announcements}

\section{Annual Meetings}

The American Pediatric Society. The Society for Pediatric Research, and The Ambulatory Pediatric Association will hold their annual meetings May3-6, 1993 at the Sheraton Washington Hotel. Washington. DC. For firther information. contact APS/SPR Association Headquarters, 141 Northwest Point Blvd.. P.O. Box 675. Elk Grove Village. IL 60009-0675. (708) 427-0205. FAX (708) 427-1305 or Ambulatory Pediatric Association. 6728 Old McLean Village. McLean. VA 22101. (703) 556-9222. FAX (703) 556-8729.

\section{Call for Abstracts}

The Society for Behavioral Pediatrics will conduct its 11th Annual Scientific Meeting on September 12-13. 1993 at the Providence Marriott in Providence, RI. We invite you to submit abstracts of research papers for consideration for presentation at the scientific sessions. ABSTRACTS MUST BE RECEIVED BY MARCH 1. 1993. For further information and abstract forms, please contact Ms. Noreen Spota at (215) 248-9168. 